disinterestedness requirements as to the operating trustee, it should solve the more significant and larger problem of providing for the efficient operation of the enterprise without concurrently placing investigation and plan formulation in biased hands.

\title{
FORMULATION OF A PLAN UNDER SECTION 77
}

SEction 77 of the Bankruptcy Acts ${ }^{1}$ was enacted hurriedly in the closing days of the last Hoover Congress to provide machinery for the conservation and reorganization of financially embarrassed railreads. In 1935, the Section was revised sentence by sentence, 2 and now represents a carefully considered attempt to improve upon the old equity receivership which has served as the vehicle for reorganizing over 1,000 carriers since $1870 .^{3}$ This Comment will be confined to comparison of equity methods with the new procedure for forrulating a reorganization plan and to suggestions aimed at retaining the better features of both.

The directors and investment bankers who held the purse strings of the road precipitated the typical equity receivership through a suit in which a friendly creditor lent his name to a creditor's bill brought before a federal judge who appointed a receiver, usually an officer of the corporation, to operate the company and protect its assets from dissipation. A plan of reorganization was then worked out by the bankers as reorganization managers, and approred by protective committees which had obtained depusits of certificates from investors. To circumrent dissenting security holders, rescort was had to "judicial sale" of the railroad-a foreclosure instituted by the hondholders."

1. 47 Stat. 1474 (1933), 11 L. S. C. $\$ 205$ (1934).

2. 49 Stat. 911 (1935), 11 L. S. C. $\$ 205$ (Supp. 1930 ).

3. Thirty-one major roads were reurganized hetwcen 1914 and 1933, when the new statute was enacted. See speed hy Interstate Cimmurie Cimmissiuner (then Chairman) Mahaffie, as reported in X. Y. Times, Xiv. 12. 193". P. 3\%. o.1. 4.

Lise of the equity receivership to facilitat: railruad reorsanizatiuns constituted a notable chapter in the history of American "high-finance." Sreculative investment and orerexpansion of physical property necessitated constant readjustment of financial structures. involving an exchange of securities and reduction of fixed charges.

See generally on the history and technique of the receivership, Dewric, The Fisaxcial Policy of Corforations (3d cd. 1934) 1140 it siq.

4. Cravath, The Reorganization of Corporations, in Sone Legal Puases of Cofporate Fisancisg, Reorganizatiox axd Regtlatiox (1917) 156-161; Dewisg, op. cit. supra note 3 , at 1119 .

5. A judicial sale based on the upset price was the hub of the equity receivership. The reorganization managers controlled through the protcctive committecs a substantial number of the first layer of bonds upon which default had been male. Foreclosure pro- 
Legally, dissenting security holders were entitled to no more than a proportional cash share of the "upset price" at which the property was foreclosed. This pro rata division amounted to so little that dissenters were often forced to enter the reorganization and accept the new securities. ${ }^{6}$ The new company, in whose name the reorganization managers had purchased the property, then proceeded to exchange new securities for old on the basis of the agreed plan.

The equity process was unsatisfactory to the banker-reorganizer, the investor and the public. In using the creditor's bill as an elaborate attempt to simulate legal combat, the reorganizer was constantly beset by procedural pitfalls. ${ }^{7}$ Unfriendly state receiverships prior to the prearranged federal proceedings might divide the railroad into several sections, each under the custody of a separate state court. ${ }^{8}$ Even when administration of the property was successfully maneuvered into a federal tribunal, the latter's jurisdiction was limited to a single district, and cumbersome ancillary receiverships were required. ${ }^{9}$ In addition, decisions of the Supreme Court tended to magnify the theoretical rights of disapproving creditors. ${ }^{10}$ Despite the judicial sale, minorities possessed sufficient power to exact valuable concessions, especially since depression capital markets made large cash payments to dissenters prohibitive.

Investors often had little voice in the disposition of their property. ${ }^{11}$ The proceedings were dominated by investment bankers, who were prompted by a practical desire to take care of issues they had sponsored, ${ }^{12}$ and sometimes

ceedings were instituted by a selected bondholder in the receivership court. The judge fixed an "upset price" well beyond the reach of any independent purchaser group, but far below the real value of the road. Instead of bidding to the full amount of the bonds under their control, the reorganizers offered only enough bonds to equal a figure slightly above the upset price, and purchased the property on behalf of the new company. See generally Spring, Upset Prices in Corporate Reorganization (1919) 32 Hakv. L. REV. 489.

6. The dissenter's dilemma is fully discussed in Lowenthat, The Investor Pays (1933) 292.

7. See address by Robert T. Swaine to Annual Meeting of Railway Accounting Officers at Detroit, July 1, 1936, published by the Association of American Railroads.

8. See Buck v. Colbath, 3 Wall. 334, 341 (U. S. 1865).

9. Booth v. Clark, 17 How. 322 (U. S. 1854); Guaranty Trust Co. v. Fentress, 61 F. (2d) 329 (C. C. A. 7th, 1932).

10. Chicago, R. I. \& P. R. R. v. Howard, 7 Wall. 392 (U. S. 1868); Louisville Trust Co. v. Louisville \& C. Ry., 174 U. S. 674 (1899); Northern Pacific Ry. v. Boyd, 228 U. S. 482 (1913); see Cravath, supra note 4, 191-198; Swaine, Reorgantiaation of Corporations: Certain Developments of the Last Decade in Some Legal PHASES of Corporate Financing, Reorganization and Regulation (1926-1930) 133. See also note 40 infra.

11. The abuses affecting investors are fully discussed in Report of Coordinator Eastman to the I. C. C., Doc. No. 119, 73d Cong., 2d Sess. (1934) 3; Lowentual, TuE Investor Pays (1933); Securities and Exchange Commission, Report on Protective and Reorganization Committees (1936-1937) Part I.

12. But see S. E. C. REPoRT, op. cit. supra note 11 , Part I, 874, asserting that this "moral obligation" to sponsored issues was merely an excuse for seizing control of the reorganization machinery. 
sought to maintain profitable connections and share in the liberal reorganization fees. Protective committees were formed and their personnel chosen at the suggestion of the bankers. Lists of security holders were available only to the bankers' committees. Deposits of securities were obtained by high pressure methods, and depositors bound in advance to whateyer plan the committees adopted. Some of the new money exacted from stockholders provided exorbitant fees for the reorganization managers and their attorneys. ${ }^{13}$ Since the old management controlled the formation of the new enterprise, assets in the form of mismanagement suits against officers, directors, and bankers were rarely realized. ${ }^{14}$

Aside from the protection of investors, public welfare requires a stable financial reconstruction in order to assure maintenance of efficient service. Yet the new capitalizations established by the plans were often more unsound than the old. ${ }^{15}$ The Interstate Commerce Commission had no power to protect the public interest in reorganizations until 1920, when the reorganized company, at the very end of receivership, was required to obtain Commission approval of its new securities. ${ }^{16}$ Due in part to the reluctance of the Commission to interfere with a plan so near fulfillment, such applications were invariably allowed. ${ }^{\mathbf{}}$

Faced with a number of imminent reorganizations in 1933, reorganizers and reformers alike sought new legislation going beyond the existing equity process. $^{18}$ The present statute, based upon the bankruptcy power of Congress, embodies suggestions of all groups concerned. Although it does not pre-

13. Reorganization of the Western Pacific (1915-16) cost $\$ 2,000,000$; the Wabash (1911-1916) $\$ 3,449,500$, Pere Marquette (1912-1917) $\$ 2,679,000$. The all-time high was recorded by the Cricago, Milwaukee and St. Paul (1925-28), whose expenses were estimated variously from $\$ 4,950,050$ to $\$ 6,495,000$. See Paston, Railrood Reccizerships ard Reorganizations (1933) 1 Ed. ResEArCH Rer. 23, 28.

14. See (1937) 47 YALE L. J. 285 at 286.

15. Eight railroads reorganized between 1915 and 1933 had larger capitalizations after reorganization than before. See Mahaffie, sutgra note 3.

16. Section 20a of the Transportation Act, 41 STAT. 494 (1920), 49 U. S. C. $\$ 20 a$ (1934), gives the Commission power to approve all issues of securities. Sce note 59, infra.

17. "The Commission has not rejected outright any of the forty odd plans submitted to it since 1920, though in a few cases it has required minor changes." Moulron;, TrEe American Transportation Problear (1933) 325.

18. Solicitor General Thacher had commenced work on the measure as early as 1931. The original draft embodied mainly those changes sought by the reorganizers, but the statute passed in 1933 contained many suggestions of the reformers as well. See Swaine, supra note 7. The amendments of 1935 went even further toward reform by way of government intervention.

For discussion of the 1933 act, see Lowenthal, Fhe Railroad Reorganization Act (1933) 47 HaRv. L. Rev. 18; Rodgers \& Groom, Reorganization of Railroad Corporations Under Section 77 of the Bankruptcy Act (1933) 33 CoL L. Rev. 571; Wehle, Rairoad Reorganization under Section 77 of the Bankruptcy Act: New Leyislation Suggested (1934) 44 Yale L. J. 197. The 1935 Amendments are analyzed by Craven and Fulter, 
clude recourse to the old equity procedure, it affords an alternative and more effective device for the rehabilitation of financially embarrassed roads. Under Section 77, as amended, reorganization proceedings are initiated by the debtor railroad in a federal district court, which takes jurisdiction over the entire property of the road.18 Subject to the ratification of the Interstate Commerce Commission, a trustee is appointed by the court. ${ }^{20}$ Within six months, the railroad must submit a plan of reorganization to the Commission, and permission may be obtained by all interested parties to intervene in the hearings held before the Commission upon the feasibility of the plan. ${ }^{21}$ Protective committees, however, may not solicit proxies or deposits until after Commission investigation and consent. ${ }^{22}$ The Commission then approves a plan which may be different from any of those suggested, but which must conform to certain standards set by the act, the most important being that fixed charges shall be adequately covered by the probable prospective earnings of the road. ${ }^{23}$ The Commission's report is certified to the court, which in turn hears objections of all interested parties. If the judge disapproves the plan, it is referred to the Commission for further action, but should the plan be found to comply with the equitable rights of the parties, the court instructs the Commission to submit the proposal to the interested creditors and stockholders for their approval. The results are then transmitted to the court, and the plan may be confirmed if two-thirds of each class concerned have signified their assent, or, in the absence of such assent, if the judge finds, inter alia, that the plan "makes adequate provision for fair and equitable treatment of the interests or claims of all those rejecting it."24 Exhaustive provisions cover the execution of a confirmed plan. Finally, the fees fixed by the court for compensation of trustees, committees and their attorneys must be within maximum limits set by the Commission. ${ }^{25}$

Among the acknowledged achievements of Section 77 is the elimination of procedural difficulties incident to the use of the creditor's bill, and the substitution therefor of machinery designed especially for reorganization. Another objective of the reorganizers was realized by making it possible under the act for two-thirds or less of any class of securities to bind dissenters and proceed with reorganization. This provision, however, has not yet been utilized. ${ }^{20}$ Replacement of the friendly receiver with a qualified trustee has also met with

The 1935 Amendments of the Railroad Bankruptcy Law (1936) 49 HARv. L. REv. 1254; Friendly, Amendment of the Railroad Reorganization Act (1936) 36 CoL. L. REv. 27; Sunderland, Railyoad Reorganizations (1936) 2 CoRp. Reorg. 324.

19. $\$ 77 a$.

20. $\$ 77 \mathrm{c}(1)$.

21. $\$ 77 \mathrm{~d}$.

22. $\$ 77$ p. See note 64 infra.

23. $\$ 77 \mathrm{~d}$.

24. $\$ 77 \mathrm{e}$.

25. $\$ 77 \mathrm{c}(12)$.

26. See discussion in articles cited supra note 18. 
general approval.2 ${ }^{2 \pi}$ But major problems have been encountered in consummating, under Conmission leadership, a reorganization plan which composes private disputes and yet is compatible with the public interest.

One objective of Section 77 was to accelerate the process of reorganization, ${ }^{28}$ which in the average equity receivership consumed from three and onehalf to four and one-half years. ${ }^{29}$ Streamlined reorganization was intended in the provision for submitting a plan within six months, ${ }^{30}$ and in the various devices for dispensing with consents of security-holders." But despite these attempts at efficiency, ${ }^{32}$ proceedings under the Act have not been swift. ${ }^{33}$ Thirty-one railroads, including eighteen Class I properties, ${ }^{31}$ have filed under Section 77 , but only three small roads have emerged successfully reorganized. ${ }^{35}$ In one case, the petition of the debtor was dismissed. The other twenty-seven occupy various stages upon the docket of the Interstate Commerce Commission. Although the Act requires that plans be submitted within six months, the average lapse between the filing of a petition and the offer of a plan has been a year and a quarter, while four companies which entered in 1935 or earlier have tendered no proposals whatsoever. Plans submitted to the Commission have been referred to its Bureau of Finance for hearings and a report. Twenty-two debtors, thirteen of them Class I roads, have appeared before the Finance Bureau. In three cases, hearings have been suspended at the request of the parties. In nine, including only one major property, the Bureau has concluded its investigations and recommended a plan to the Commission. The remaining ten, all Class I carriers, are still upon the Finance Docket, and have been there for an average of a year and a half since the filing of a plan.

Delay in the filing of a reorganization plan may be excused on several grounds. The six months rule was not inserted until 1935. Hasty reorgani-

27. See (1937) 47 Yale L. J. 285.

28. The Supreme Court, in Continental Illinois Nat. Bank \& Trust Co. v. Chiago, R. I. \& P. Ry., 294 U. S. 648, 685 (1935), interpreted the original act as requiring, above all, that reorganizations be speedy. It was felt, however, that this decision put more emphasis on haste than was desirable. H. R. Rex. No. 1283, 74th Cong., 1st Sess. (1935) 3. Subsection (g) of the present act authorizes dismissal only if there is "undue delay in a reasonably expeditious reorganization of the debtor."

29. See I. C. C., Bureau of Statistics, Statement No. 2864, File No. 52-A-2; I. C. C. AnN. Rep. on Statistics of RaIlways in U. S.

30. $\$ 77 \mathrm{~d}$.

31. $\$ 77 \mathrm{e}$.

32. $\$ 77 b, c$ (4) (5) (10) (11) were also designed to malse reorganizations more efficient.

33. See a typical "financial" editorial objecting to the delay in the Wall St. Journal, Jan. 13, 1937, p. 4, col. 1.

34. Class I railroads operate $93 \%$ of the total mileage in the United States, and earn about $97 \%$ of the total revenues. RaIlway axd Isoustrinz Cospesduzs (May, 1937) 8.

35. The Copper Range, the Reader, and the Chieago, South Shore and South Bend. The first two are owned by a mining and a lumber company respectively, while the third is an electric interurban line. The largest operates but 113 miles of track: 
zation during the depression period was not encouraged, for plans based upon the abnormally low earnings up to 1935 would have required such sacrifices by security holders as to make rejection by them certain; and the act was intended to provide a haven in which distressed roads could weather depression storms. ${ }^{36}$ But once a plan has been filed and hearings commenced the delay cannot be justified upon this ground. Continued inability to consummate a plan has been ascribed to hopelessly low revenues, but income for 1936 and 1937 has approached the 1930 average $^{37}$ without any noticeable acceleration of proceedings. Although in a few instances earnings have lagged and the parties themselves are unwilling to hasten matters, there are many others in which everyone concerned is anxious for a speedy solution. In these cases it is difficult to determine any single factor which is responsible for the protraction of the rehabilitation process.

The reasons for delay can be ascertained only by an examination of the problems encountered and the methods used by the Commission in the formulation of a plan. And since speed is a subordinate objective to the consummation of an equitable reorganization satisfactory to all interests, a charge more serious than delay is that the Bureau's manner of conducting hearings has failed to result in plans upon which the parties have been persuaded to agree.

Whenever investor-groups are so well organized as to make their co-operation indispensable to a successful reconstruction, negotiation toward an agreement among owners of all classes of securities has been an objective of reorganization managers. ${ }^{38}$ If railroad earnings fail to meet debt charges, various creditors possess theoretical remedies of uncertain value. Long lawsuits would be required to assert them, and foreclosure of a mortgage upon one division of a railroad would be useless. Investments can be recovered only through rehabilitation of the property and resumption of interest and dividend payments. Therefore the inevitable conflict between vengeful action to enforce remedies and the more practical desire to restore the company's credit usually results in adoption of the latter course. Senior bondholders must negotiate with junior interests to prevent delay and sometimes to obtain new money. They must decide what terms to accept. Similarly, junior creditors possess certain subordinate rights. Their power to demand a cash payment based upon the sale value of the property ${ }^{39}$ is tempered by their desire

36. See discussion by the authors of the 1935 Amendments in Craven and Fuller, supra note 18 , at $1262-5$.

37. See Railway \& Industrial Compendium (May 1937) 8 et seq.

38. For a penetrating analysis of these inter-class relations, see Foster, Conflicting Ideals for Reorganization (1935) 44 YalE L. J. 923; Dodd, Reorganization Throngh Bankruptcy: A Remedy for What? (1935) 48 HARv. L. REv. 1100.

39. Formerly this value was the "upset price" set by the court (see note 5 supra), but now value must be fixed by the Commission, "determined on a basis which will give due consideration to the earning power of the property, past, present, and prospective, and all other relevant facts." Not too much emphasis is to be placed upon reproduction cost new or upon original cost. \$77e. See Craven and Fuller, supra note 18, at 1272. 
to secure a better settlement by obtaining new securities which will reflect any increase in earnings. They too are anxious for compromise. Although the stockholders have no legal right to consideration unless the corporation is solvent, ${ }^{40}$ their strategic power to block reorganization makes their cooperation desirable. They must often be relied upon as the source of new money, and in return must be granted representation in the new company. Were they to be eliminated, either a cash payment based upon their equity in the property, or long delay while the company was being adjudicated insolvent, would be required. All interests have power to command a share in the new enterprise, and all have much to lose by obstinacy and delay. The stage is set for bargaining.

The banker-management group which dominated the equity receivership had perfected an effective machinery for the elimination or compromise of many of the natural conflicts among investor-classes. By judicious dispensation of patronage, the vital support of the mortgage trustees and the protective committees was obtained. ${ }^{22}$ The bankers were the medium through which the different classes of security holders resolved their disputes. ${ }^{43}$ Minor opponents to the projected plan were bought off or smothered, and the major conflicts were seltled by bargaining and mutual concession. The plan finally presented to the court usually had the approval and active support of all the spokesmen for majority groups. Like a well-organized political machine, the bankers selected the ticket and brought out the votes.

40. Northern Pacific Ry. v. Boyd, 228 U. S. 482 (1913) is the leading case on the "trust fund" principle. See Wehle, supra note 18, at 208. This oft-cited case held that where the stockholders, who stand below the unsecured creditor in the hierarchy of legal priorities, are given new stock upon payment of an assessment, while the unsecured creditor received nothing, the latter might follow the assets of the old company into the hands of the new, and recover the amount of his claim against the new corporation. Cravath, in 1916, described the Boyd case as a "veritable demon incarnate standing across the path of the reorganizers," but a decade later Swaine, supra note 10, questioned whether the demon had not become "reasonably domesticated."

41. Subsection e. See the comment made by Commissioner Afahafie on the amount that it would have cost the St. Louis-San Francisco to discover that it was legally insolvent. Hearings before Committee on Interstate Commerce on S. Res. 7I, 74th Cong., 1st Sess. (1935) 126. On the difficulties of dispensing with the cooperation of shareholders, see Dodd, supra note 38 , at 1123 .

42. See Lowenteal, op. cit. supra note $6,155,187$; S. E. C. Rerort, op. cit. supgra note 11, Part I, 872-3. The support of the indenture trustee was required in order to prepare for reorganization in advance of his announcement of default and to control possible foreclosure proceedings. The trust companies found it profitable to follow the bankers and secure some of the lucrative reorganization business-depositary fees, certification fees, etc.

43. Disputes were largely with "outside groups," since the banker-controlled committees cooperated with the reorganizers. S. E. C. REPont, of. cit. supra note 11, Part I, 878-883. Sometimes outside dissenters possessed enough obstructive power to exact valuable concessions. But when the reorganizers chose to proceed without placating a weaker outside group, the latter usually found it very difficult to get any help from the court, which was often swayed by the number of votes helind the reorganizers' plan. 
The framers of Section 77 recognized that a successful reorganization required such leadership, but sought to curb its ill effects by removing the banker, motivated by self-interest, and by substituting the Interstate Commerce Commission.44 It seems, however, that the Commission has been unwilling to assume the banker's burden. Conflicts within and among different classes of security holders have not been smoothed over by conciliation and compromise under Commission guidance, but have been sharpened by legalistic arguments before the Commission as to the "justice" of the respective claims. ${ }^{45}$ The manner in which the Bureau of Finance has failed to coordinate the desire of all parties to negotiate is strikingly illustrated in the case of the Western Pacific, the single Class I carrier for which the Bureau has recommended a plan. ${ }^{46}$ The railroad's capital structure is simple. There are first mortgage bondholders, three junior creditors ${ }^{47}$ and one holding company stockholder. Two major disputes divide the parties. The three junior creditors, owning notes which are secured in varying proportions by a General and Refunding Mortgage, contest among themselves whether apportionment of new securities should be based on the face value of the notes or on the collateral holdings. The second conflict is the usual one over allocation of new stocks and bonds among the three classes of investors. ${ }^{48}$ Separate plans were submitted to the Bureau by the debtor, the first mortgage bondholders, and by one of the junior creditors. ${ }^{40}$

Extensive public hearings were held before a single examiner, to whom briefs were submitted. No compromise among the parties was arranged under Commission leadership. Instead, the Bureau of Finance prepared a report, much in the manner of a judicial opinion, which rejected the three plans proposed and announced a fourth of its own. ${ }^{50}$ In addition to inserting provisions which aim to protect the public interest, ${ }^{51}$ the Bureau has attempted to adjudicate purely inter-party differences. ${ }^{52}$ Exceptions to this plan have

44. See statement of Senator Couzens, 76 Cosc. Rec. 5127 (1933); Craven and Fuller, supra note 18, 1284-5.

45. See, e.g., Brief on behalf of the Insurance Group Committee in the Denver and Rio Grande Western reorganization, Finance Docket No. 11,002.

46. The history of the Western Pacific proceedings may be found in the Interstate Commerce Commission's Finance Docket No. 10,913.

47. Reconstruction Finance Corporation, Railroad Credit Corporation, and A. C. James Co., a banking firm closely identified with the railroad.

48. There is also a third, but minor point of disagreement on whether the First Mortgage or the General and Refunding Mortgage has a prior lien upon the Northern California Extension, a newly-constructed branch line expected to be of great value to the company. See Alley, An Appraisal of Some Phases of the Corporate Reorganization Statutes (1937) 3 CoRp. Reorg. 443, 450, note 131.

49. A. C. James Co. filed a plan in October, 1936. See (1936) 143 Comm. \& Fin. Chron. 2868.

50. The Report is given in (1937) 145 Comm. \& Fin. Chron. 963.

51. See notes 82,84 infra.

52. New securities were awarded to the junior creditors on the basis of collateral holdings rather than the face value of the notes, while the strict priority rights of the 
been filed by nearly all disputants, and hearings will soon commence before the Commission proper. After two years of 77 proceedings, the three classes all disagree with the Commission and are no nearer an agreement among themselves.

Barring extraordinary coercion by Commission and Court, ${ }^{, 3}$ no plan can succeed without the support, obtained by mutual negotiation and compromise, of each organized group which controls enough votes to block ratification by its class. A decision by an impartial tribunal as to relative legal rights makes each class feel that it has been given too little and deprived of too much. Of course, the parties themselves are to blame for the legalistic nature of the arguments. Although bondholders have alway's indulged in voluminous discussion of creditors' rights, they have done so only as a preliminary to compromise and eventual agreement. ${ }^{54}$ So long as secondary creditors and stockholders have the power to impede any reorganization which attempts to proceed without them, the theoretical priorities of different closses are useful only as bargaining weapons. History of past reorganizations indicates that while occasional victories have been won for priorities in the Supreme Court after protracted litigation, the senior bondholders prefer to compromise their differences, paying in theoretical legal rights for actual cooperation of junior interests in restoring the company's credit, ${ }^{55}$ and in returning the property to private management.

But since strategy and often stubbornness forbid a class of security holders to suggest compromise itself, lest the offer be interpreted as a sign of weakness, some "outside" conciliator must take the initiative. This was formerly the banker's function. Today, round table conference under Commission leadership seems the wisest solution.

Administration of similar problems in the reorganization of industrial corporations under Section 77B suggests a method of supplying the missing initiative. When banker leadership has not already composed interparty differences, the Bankruptcy Court has often summoned all of the disputants to an informal conference in chambers. Under the respected persussion of the judge, empty discussions of rights are quickly transformed into serious

First Mortgage Bondholders have not been observed. The holding company stod:holder, Western Pacific Railroad Corp., is to be admitted upon subscribing for the new $\$ 10,000,000$ first $4 \%$ mortgage upon terms so advantageous that the bonds will probably bring more than par in the market. See, as criticizing the above provisions, In re Western Pacific R. R. Reorganization, Finance Dodket 10913, Brief for Bondholder group in Support of Exceptions to Proposed Report of the Bureau of Finance, also Brief for A. C. James Co., a Secured Creditor, in Support of Exceptions.

53. Eren if whole classes reject the plan, the court may yet approve if it believes that the plan "makes adequate provision for fair and equitable treatment for the interests or claims of all those rejecting it." See note 85 infra, for discussion of this power.

54. See analysis by Foster, supra note 38, 951-954.

55. Ibid. at 927. 
negotiation. ${ }^{56}$ Similarly, a Commissioner, or an Examiner from the Bureau of Finance could arrange for and direct informal meetings ${ }^{67}$ throughout the period of negotiation and formulation of a plan, and firmly insist upon the compromise of interparty disputes. His prestige, and his assurance of Commission cooperation, would hasten resolution of conflicts. ${ }^{58}$ Such a course must have been considered by the Commission. Hesitation has probably been due to several factors. The Interstate Commerce Commission is an established, quasi-judicial body some fifty years of age. Its methods are settledlengthy public hearings characterize its procedure, which is well suited to its normal rate making and abandonment functions. ${ }^{59}$ As there are eleven Commissioners, the one presiding at the proposed informal meeting can not speak for the others, for the system of revolving the chairmanship has prevented continued coordination of policy under one leadership. It is a strange paradox that a judicial tribunal can successfully administrate informal negotiation and compromise in $77 \mathrm{~B}$ proceedings, while an administrative agency is so awed by its own judicial prestige that it is unable to do the same for $77 . .^{60}$

It is conceivable that negotiation and compromise might be dispensed with in cases where all security holdings are small and widely dispersed. ${ }^{01} \mathrm{Bc}$ wildered by the intricacies of the plan, ignorant of their collective power to obtain better terms, and anxious to salvage something as soon as possible,

56. The soundness of the plans evolved has, hoivever, been questioned. See Comment, (1937) 47 YALE L. J. 229, 237; Spaeth and Friedberg, Early Developincuts under Section $77 B$ (1935) 30 ILL. L. REv. 137, 176.

57. Reorganization negotiation might be analogized to political "log-rolling." Practical statesmanship must recognize that both are necessary, and that neither can flourish in the open.

58. With a Commissioner presiding, none of the negotiators could "walle out" and refuse to compromise, for fear of incurring the displeasure of the tribunal which must eventually recommend a plan. Speedy settlement would probably be the usual result of a round-table parley. The plan agreed upon, supported by both Commission and investors, would have little trouble getting through the court.

59. Since 1920, the Commission has also been charged with the duty of approving all issues of securities. While the time consumed by the Bureat of Finance and the Finance Division in investigating each application is perhaps unavoidable, it would be impossible for underwriters to agree with the railroad upon terms of the offering and then wait idly for over a month while the Commission approved the issuc. The practice has therefore developed of marketing securities to the ultimate purchisers before Commission approval, on an "if, as and when" basis. Experience since 1920 has indicated that there are definite precedents upon the basis of which Commission approval may be safely predicted.

60. This statement is not intended to reflect upon the Commission's methods in discharging its duties of rate making, valuation, supervision of accounting practices, and the approval of security issues. Adjudication after investigation may be the best method of administering such responsibilities. But it is submitted that the problems of reorganization cannot be solved by such an approach. See page 261, infra.

61. In the reorganization of the Missouri Pacific system, there are 50,000 bondholders, 10,000 stockholders, and 2,500 general unsecured creditors. See Craven and Fuller, supra note 18,56 n. 8. 
scattered investors might approve any proposal. Generally, however, there are active groups within many classes which control enough votes to block: ratification. Numerous insurance company-savings bank coalitions have assembled sizeable bond holdings which make their consent desirable, ${ }^{02}$ while other large creditors, like the Reconstruction Finance Corporation, own the majority of claims in their class, and their assent to the plan must be obtained. In addition junior securities of certain roads, such as the Western Pacific, are owned by a few major investors. The Commission would be constrained to defer to the wishes of the powerful blocs and promote an agreement among them, in order to consummate reorganization.

Some method should be devised, however, which would prevent the stronger groups from utilizing their bargaining position to create discriminations against other classes having no such concerted voting strength. Significant organization of scattered small investors has always been difficult to achieve. Under the equity system, the majority of these investors vere supposedly represented by protective committees which obtained deposits of securities before approving a plan. But these committees were sometimes mere puppets, created by reorganization banker-managers and manipulated by them at will, often with no thought to the real interest of the security holders who had deposited their certificates. ${ }^{63}$ The control over protective committees given to the Commission by Section 77 has been used to impose stringent limitations upon their personnel and activities. ${ }^{\text {of }}$ For this reason, and perhaps because the notorious lethargy of small investors cannot be overcome except by highpressure methods of solicitation, now disapproved, protective committees have been unable to obtain many deposits of securities. ${ }^{05}$ The institutional. investors who contributed largely to the strength of the committees have preferred under Section 77 to organize as groups of mutual institutions, under which category their activities are exempt from Commission scrutiny. ${ }^{\text {CG }}$

62. Such combinations exist in the reorganizations of the Chicago \& Eastern Illinois, Mionon, Mfilwaukee, Rock Island, Mfissouri Pacific, Frisco, Western Pacific and probably many others. See generally RaILway \& Indostaral Cosurewdiuzs (afay 1937).

63. Allegedly of such a nature were the committees in the Alilwaukee reorganiztion of 1926-1928. For extensive criticism of the committees and the deposit agreement, see Lowenthal, sipra note 6, 163-196, 307-348. See also Jackson, Securily Holder Representation in $77 B$ Proceedings (1936) 2 CoRp. Rzorg. 308.

$64 . \$ 77 \mathrm{p}$ states that no protective committee can solicit deposits or proxies without the approval of the Commission, obtained by filing an exhaustive stotement pursuant to a Regulation established by an order issued at a general session of the I. C. C on Oct. 23, 1935. C. C. H. Bank. Serv. \I 2001 (1936).

65. A Rock Island Committee, however, has obtained deposits of more than 60\% of the bonds in its class (RaIlway ANd Industrial Cosmpenduss (May, 1937) 61, while a committee for the First Terminal Bonds of the St. Louis Southwestern has secured $22 \%$ of its issue. (1937) 144 Cossas. \& Fin. Crnos. 2146.

66. Due to the restrictions upon protective committees, these interests have usually intervened as "groups of not more than twenty-five bona fide holders of securities 
Smaller investors, however, have remained unorganized. ${ }^{67}$ Their privilege to intervene and state their views is rarely exercised. Even should occasional security holders appear, they could only advocate; they would be unable to compose differences existing between whole classes either by negotiation or otherwise, for they could speak for no one but themselves.

The average investor is unfamiliar with reorganization technique; his interests can best be defended by experts. It has been suggested that the collective power of scattered security holders can most effectively be realized though representation before the Commission by selected delegates. ${ }^{68}$ To achieve a bargaining strength comparable to that of the powerful organized groups, these delegates should be empowered to bind investors in advance, for representatives with sufficient votes to block any unfavorable plan would be able to exact better terms from other classes of securities. ${ }^{60}$

While a system of representation would afford a satisfactory method of equalizing bargaining power, practical drawbacks might be found in devising an election machinery which would overcome the inertia of small investors and insure the selection of bona fide delegates. The representatives would perform much the same functions as protective committees, and a possible consequence might be the return of financial groups to a position of control. Financial experts and corporation lawyers are the logical delegates, but they are found chiefly in the service of insurance companies, savings and commercial banks, investment houses, trust companies and the railroads themselves, and might be influenced by the banker-management group. But the Commission could disqualify those clearly associated with the former management and by continuing supervision of the reorganization process, could prevent any representative from abusing his position. If the Commission were to preside at conferences throughout the bargaining period, the financial groups would probably be unable to acquire a control of the process comparable to their domination in equity. At any rate, the services of these experts are required, and bona fide performance of their duties is not inconceivable. Forty thousand bondholders would find it difficult to settle terms at a "town meeting". Vicarious negotiation cannot be avoided. ${ }^{70}$

. . or groups of mutual institutions" ( $\$ 77 \mathrm{p}$ ), under which classification they may freely pool their bonds and delegate representatives to speak for them.

67. But other groups take an exaggerated interest in the procecdings. Among the interveners have been the National Bituminous Coal Commission, the Railway Conductors of America, and four New England Governors objecting to Pennsylvania control of the New Haven.

68. Foster, Book Review (1933) 43 YALE L. J. 352, 357.

69. Ibid. Closer control over representatives could be achieved, without materially impairing bargaining strength, by permitting security holders to disaffirm allegedly unsatisfactory action taken by their representatives, whose decisions would otherwise be binding. Such a presumption of investor-assent in liquidation cases has been held constitutional. In re Mortgage Commission (1175 Evergreen Ave.), 270 N. Y. 436, 1 N. E. (2d) 836 (1936) aff'd 299 U. S. 521 (1937).

70. See Foster, supra note 68. 
Several methods of selecting representatives seem feasible. The abuses connected with the deposit agreement in equity receiverships militate against the use of that device. ${ }^{71}$ Proxies, however, do not lend themselves so readily to unethical practice. Prior to the construction of a plan, regular elections of negotiators could be held under Commission auspices. ${ }^{72}$ Like the present method of dealing with reorganization trustees, the Commission could fix salaries, set qualifications, and ratify successful candidates. Representation of a class of bondholders could also be assumed by the custodian of the mortgage under the trust indenture. While the indenture trustee often is little more than an escrow agent with composite duties to debtor and creditors, it has recently been thought advisable to make his fiduciary duties more actual than nominal..$^{73}$ As the bondholder's representative, he is already empowered to take steps in default; little more would be required to enable him to negotiate for investors in the formation of a reorganization plan. ${ }^{74}$ Bondholder organization under the mortgage indenture has been attempted successfully in Canada and England. Authorized by a vote of investors at regular meetings, the trustee may extend maturity, ${ }^{75}$ lower the interest rate, modify other terms of the mortgage, and participate in reorganization. ${ }^{70}$ At similar meetings the bondholders could focus their power in the trustee and authorize him to negotiate for them in preparing a plan. Trust indentures are common in many classes of secured and unsecured obligations. ${ }^{77}$

A third type of representative, somewhat analogous to the defender assigned to an indigent respondent, might be more preferable. Despite widespread investor apathy, there is usually a large security holder or group of holders within each class which intervenes to protect its claims. After thorough investigation of qualifications, the Commission could designate that intervening group as the representative of the entire issue. Should no such intervener appear, or should the intervener fail to qualify, the Commission could itself appoint competent representation for the class. Unless investors made some move to dislodge them, delegates for all issues could then be given power to negotiate with each other for speedy formulation of a plan under

71. See note 63 supra.

72. As suggested by Foster, supra note 68, "Let machinery be provided for bondholder-election of representatives by plurality or majority vole, or by cumulative voting, with open or closed primaries, with requirements that candidates disclose, or free themselves from, inconsistent interests; place limits upon compaign expenses, et cetera."

73. The recommendations of the Securities and Exchange Commission, contained in S. E. C. REPoRT, supra note 11, Part VI, have been embodied into the Barliley Bill, S.23H, 75th Cong., 1st Sess. (1937).

74. See for a similar suggestion, Posner, The Trustec and the Trusl IndenlureA Further Study (1937) 46 YALE L. J. 737, 798.

75. See Comment (1937) 46 Yale L. J. 1041.

76. A typical Canadian trust indenture is set out in S. E C. Report, stipra note 11, Part VI, 164.

77. See Comment (1936) 46 YAle L. J. 97. 
Commission guidance. They could be empowered to make compromise and acquit legal claims through the course of bargaining process. ${ }^{78}$

If a plan were formulated by representatives under Commission supervision and approved by the court, subsequent ratification by investors would be reduced to a mere rubber-stamping process. Approval of groups controlling large blocks of votes would usually have been obtained during the course of negotiation, while scattered small security holders either would neglect to exercise their franchise or, anxious to terminate the trusteeship, would consent to any proposal. The formality of postponing investor consent until after a plan has been negotiated seems artificial and unnecessary. ${ }^{\text {70 }}$

As a corollary to adequate machinery for the protection of investors' interests, guardianship of the public welfare is required during the formulation of a plan. Although 77 designates the Commission as the representative of the public interest, ${ }^{80}$ the scope of the tribunal's duties in that respect is undefined. Since public interest is a conveniently vague phrase bristling with argumentative connotations, it would be advisable to discover which phases of a reorganization clearly concern the common welfare. At present, railroads are required to supply efficient service at reasonable rates. The public welfare thus assumes a double aspect-protection of the public at large as the consumer of railroad services, and protection of the investor. The interest of the first group demands low fixed charges and satisfactory provisions for future financing, so that the road may operate without recourse either to the Government's coffers for loans ${ }^{81}$ or to the Government's courts and administrative agencies for repeated reorganization. In furtherance of these aims, a low capital structure ${ }^{82}$ and the elimination of hybrid securities might

78. A possible analogy is offered by Doty v. Love, 295 U. S. 64 (1935), where under a Mississippi statute permitting reopening of a closed bank if approved by threefourths of the depositors, the court appointed representatives to speak for depositors in the course of negotiation. As part of the reorganization plan, the delegates waived the statutory double liability of the shareholders in return for contribution by the latter of new money to the enterprise. Despite the contention of a dissatisfied minority depositor that the waiver of liability without his consent constituted a denial of due process, the plan of reorganization was upheld.

79. The ratification provisions of the act have been criticized as a mere "will-o"the-wisp" based upon the illusion of ratification which was the traditional technique of the equity-reorganizer. See Foster, supra note 68.

80. See $\$ 77 \mathrm{~d}$.

81. The Reconstruction Finance Corporation is a creditor of every major railroad in reorganization.

82. The Bureau of Finance has recommended a capitalization of $\$ 91,406,510$ for the Western Pacific, as contrasted with the present capital structure of about $\$ 150,000,000$, and a valuation base for rate making purposes set by the Commission at $\$ 146,940,649$. See (1937) 145 Comm. \& Fin. Chron. 963.

It may be, however, that the Western Pacific proposal is a mere trial balloon sent up by the Commission as a warning of what will happen if the parties fail to agree among themselves. Should all the interests in a particular reorganization reach an agreement on the details of a plan based upon a much higher capitalization than the 
also be required.83 Since such steps toward a sound financial framework also involve possible benefits to investors, ${ }^{84}$ it is clearly wilhin the province of the public interest to set maximum limits for debt charges and capitalization. Within these bounds, however, there is still to be solved the major problem of a reorganization plan-such allocation of new securities as will resolve conflicting claims of different investor-groups.

By shifting focus from the public at large to the investor public, and by expanding the flexible notion of public interest, it can be argued that it is the duty of the Commission to pass judgment upon these inter-party disputes. Where security-holdings are small and scattered, and adequate representation is difficult to achieve, it might be practical for the Commission to assume this greater burden and write a plan attempting to adjudicate conflicts among classes. But where powerful investor groups exist which control enough votes to block ratification, a plan of Commission authorship can hardly be consummated, ${ }^{85}$ unless the proposal is equally appealing to all classes. Within these two extremes are many cases in which it would be difficult to predict the practical consequences of Commission adjudication. But the hypothesis of a plan written by a government agency is an extension, unwarranted by the present framework of 77 , of the traditional concept that reorganization is primarily a composition with creditors, worked out by the investors themselves. In addition to resolution of questions which are clearly problems of public interest, the Commission's present functions appear to be to proffer ethical suggestions respecting contradictory investor-claims, and to stimulate accords by encouraging a process of negotiation among representatives of the various investor classes.

Bureau of Finance would prefer, it is not unlikely that the Commission would nerertheless approve. Termination of the receivership, return of the road to the control of its owners, with its beneficial effect upon railroad securities generally, might be felt to outweigh possible advantages of a smaller capital structure.

83. The Bureau's Reports for the Louisiana \& N. W. R. R. [see (1937) 144 Comar. \& Fin. Crrow. 2134] and for the Spokane International [see (1937) 145 Comrr. \& Fin. ChroN. 622] both recommend substitution of common and preferred stock for the debentures and income bonds proposed by the parties for distribution to former first mortgage bondholders. Future financing would be simplified by the elimination of income bonds and similar hybrids.

84. But investor representatives have raised strong objections to such proposals. See statement of Spokane International bondholder committee in (1937) 145 Coxss. \& Fin. Chron. 622; see Brief on behalf of Bondholder Group in support of Exceptions to the Report of the Bureau of Finance, pp. 6-8, Western Pacific R. R. Reorganization, Finance Docket 10913.

85. The consent of investors could be dispensed with, however, if the plan, in the opinion of the court, "makes provision for fair and adequate treatment for the interests and claims of all those rejecting it." Adoption of such a course, however, seems unlikely. The judge would probably be very reluctant to approve as fair and equitable a plan opposed by a majority of investors. In addition, the constitutionality of the above provision has been doubted by all but one of its commentators. Sce Fn:letter, Princtples of Corporate Reorganization (1937) 448; Friendly, supra note 18, 32-36. But see Craven and Fuller, id. at 1278. 